\title{
MINAT GENERASI MILENIAL MENGGUNAKAN E-WALLET LINKAJA: PERSPEKTIF TEORI PERSEPSI DAN PERILAKU
}

\author{
MILLENNIALS INTEREST IN USING LINK AJA E-WALLET: \\ THEORY OF PERCEPTION AND BEHAVIOUR PERSPECTIVE
}

\author{
Qristin Violinda*)1, Nakita Via Khorunnisya*) \\ *) Universitas PGRI Semarang \\ Jl. Sidodadi Timur No 24, Semarang 50232, Indonesia
}

\begin{abstract}
This study aims to analyze the effect of perceived convenience, perceived benefits, perceived risk and trust on behavior using the LinkAja e-wallet on Universitas PGRI Semarang students. This study uses quantitative research, namely the results of research in the form of statistical figures. Data collection using a questionnaire, with a convenience sampling sampling technique. The respondents of this study were 106 students of FEB Universitas PGRI Semarang Class of 2017-2020. The results showed that the perception of convenience and trust had a positive and significant effect on behavior using the LinkAja E-Wallet while the perceived benefits and risks had a negative and significant effect on behavior using the LinkAja E-Wallet. The importance of implementing TAM (Technology Acceptance Model) for company management is to maintain the quality of company management which will have an impact on the quality of the company's products. So, later the output of the company can satisfy the expectations of customers.
\end{abstract}

Keywords: perceived ease, perceived benefits, perceived risk, trust, and use behavior

\begin{abstract}
Abstrak: Penelitian ini bertujuan untuk menganalisis pengaruh persepsi kemudahan, manfaat yang dirasakan, risiko yang dirasakan dan kepercayaan terhadap perilaku penggunaan $e$-wallet LinkAja pada mahasiswa Universitas PGRI Semarang. Penelitian ini menggunakan penelitian kuantitatif, yaitu hasil penelitian berupa angka-angka statistik. Pengumpulan data menggunakan kuesioner, dengan teknik convenience sampling. Responden penelitian ini adalah 106 mahasiswa FEB Universitas PGRI Semarang Angkatan 2017-2020. Hasil penelitian menunjukkan bahwa persepsi kenyamanan dan kepercayaan berpengaruh positif dan signifikan terhadap perilaku menggunakan LinkAja E-Wallet sedangkan persepsi manfaat dan risiko berpengaruh negatif dan signifikan terhadap perilaku menggunakan LinkAja E-Wallet. Pentingnya penerapan TAM (Technology Acceptance Model) bagi manajemen perusahaan adalah untuk menjaga kualitas manajemen perusahaan yang akan berdampak pada kualitas produk perusahaan. Sehingga nantinya output perusahaan dapat memuaskan harapan pelanggan.
\end{abstract}

Kata kunci: persepsi kemudahan, persepsi manfaat, persepsi risiko, kepercayaan, perilaku penggunaan

\footnotetext{
${ }^{1}$ Alamat korespondensi:

Email: qviolinda@upgris.ac.id
} 


\section{PENDAHULUAN}

Teknologi finansial ini muncul akibat perubahan gaya hidup masyarakat yang semakin modern dan kini didominasi oleh kecanggihan teknologi yang pesat. Salah satu jenis fintech adalah e-wallet. Dalam Peraturan Bank Indonesia Nomor 18/ 0/PBI/2016, Pasal 1 Ayat 7, tentang Penyelenggaraan Pemrosesan Transaksi Pembayaran dijelaskan bahwa dompet elektronik (e-wallet) adalah layanan penyimpanan data alat pembayaran elektronik. Ini termasuk instrumen pembayaran kartu dan/atau dompet elektronik atau cryptocurrency, juga dapat menampung dana untuk melakukan pembayaran. E-wallet yang banyak digunakan oleh masyarakat antara lain Gopay, OVO, LinkAja, DANA, Shopee Pay, dan lainnya.

E-wallet memberikan banyak kemudahan bagi pengguna seperti pembayaran non tunai, pembayaran tiket kereta api, isi ulang pulsa, pembayaran tagihan listrik, dll. Kenyamanan yang dibawa oleh $e$-wallet tentu menarik orang untuk menggunakannya, tetapi $e$-wallet LinkAja benar-benar turun peringkatnya dari tahun ke tahun. Beberapa faktor yang memengaruhi downgrade yaitu persepsi kenyamanan, persepsi manfaat, persepsi risiko, dan kepercayaan masyarakat terhadap penggunaan e-wallet LinkAja. Di bawah ini adalah daftar $e$-wallet terbesar di Indonesia tahun 2017 - 2019.

Berdasarkan Tabel 1, dapat dijelaskan bahwa e-wallet LinkAja mengalami penurunan dari tahun ke tahun, pada tahun 2017 di peringkat dua, tahun 2018 di peringkat 3 , dan tahun 2019 - 2020 di peringkat 4, padahal seperti diketahui bahwa $e$-wallet LinkAja termasuk $e$-wallet yang cukup terkenal di masyarakat.

Tabel 1. Daftar E-wallet Terbesar di Indonesia

\begin{tabular}{lcccc}
\hline \multirow{2}{*}{ Nama Provider } & \multicolumn{4}{c}{ Peringkat } \\
\cline { 2 - 5 } & 2017 & 2018 & 2019 & 2020 \\
\hline Gopay & 1 & 1 & 1 & 1 \\
LinkAja & 2 & 3 & 4 & 4 \\
OVO & 3 & 2 & 2 & 2 \\
Go Mobile by CIMB & 4 & 4 & 6 & 5 \\
Jenius & 5 & 5 & 5 & - \\
DOKU & 6 & 7 & 9 & 8 \\
Sakuku & 7 & 8 & 7 & 9 \\
Uangku & 8 & 8 & - & - \\
Mega Mobile & 9 & 10 & - & - \\
i.saku & 10 & 8 & 7 & 6 \\
\hline
\end{tabular}

Kepercayaan adalah sesuatu yang berkaitan dengan kepercayaan dan integritas layanan sistem (Daniel Koloseni, 2017). Teknologi tepercaya akan bekerja dengan baik. Jika masyarakat mempercayai produk atau jasa yang ditawarkan, hal ini akan mendorong mereka untuk menggunakannya (Chauhan, 2015). Tingkat kenyamanan adalah sejauh mana seseorang percaya bahwa menggunakan sistem tertentu tidak memerlukan kerja keras, tetapi di halaman resmi LinkAja, pengguna sebenarnya kesulitan untuk menggunakan aplikasi, misalnya, saat membuka aplikasi LinkAja, akun pengguna direkam secara otomatis. keluar dan sangat sulit untuk masuk kembali karena mereka harus memverifikasi alamat email mereka terlebih dahulu.. Seharusnya akun yang sudah masuk kedalam aplikasi tidak seharusnya keluar secara otomatis dan tetap masuk walaupun tidak sedang membuka aplikasi tersebut. Hal tersebut yang membuat pengguna menjadi kesulitan sehingga pengguna harus menghubungi customer service untuk menanyakan hal tersebut.

Berdasarkan data, terlihat bahwa jumlah pengguna $e$-wallet LinkAja mengalami penurunan. Hal ini dapat terjadi karena ada faktor-faktor yang memengaruhi perilaku pengguna, seperti dalam penelitian (Davis, 1989) kemudahan penggunaannya. Meskipun dompet elektronik (e-wallet) telah membawa manfaat dan kemudahan bagi pengguna, namun pada kenyataannya masih ada sejumlah pengguna yang menolak menggunakan teknologi ini karena faktor ketidakpastian dan keamanan. Faktor risiko keamanan ini harus diperhitungkan oleh penerbit dompet elektronik (e-wallet) untuk meminimalkan persepsi pengguna terhadap risiko transaksi yang mungkin timbul. Selain itu, faktor kepercayaan juga berperan penting dalam menerima teknologi baru seperti e-wallet, tanpa kepercayaan pengguna tidak akan menggunakan teknologi baru. Hal ini juga sejalan dengan penelitian yang dilakukan oleh Budiman H (2020) yang menegaskan bahwa strategi pertumbuhan digital harus terstruktur dengan baik untuk meningkatkan kepercayaan pelanggan.

Dari data tersebut, aplikasi LinkAja yang menunjukan penurunan yang signifikan dari peringkat kedua menjadi peringkat ketiga dan akhirnya menjadi peringkat keempat. Menurut penelitian Kusuma Aldo Putra dan Syahputra, (2020) mengatakan bahwa persepsi kemudahan dan persepsi manfaat berpengaruh pada sikap pengguna $e$-wallet. Begitu juga dengan penelitian Rahmawati Y.D dan Yuliana, (2020) mengatakan 
bahwa persepsi yang menyangkut manfaat, kemudahan dan keamanan berpengaruh terhadap jumlah konsumen yang akan memakai $e$-wallet.

Pendekatan model TAM melalui persepsi kemudahan, persepsi manfaat, persepsi resiko, kepercayaan dinilai mampu menjadi salah satu pemecahan masalah yang dihadapi oleh E-wallet LinkAja. Pemecahan masalah E-wallet LinkAja tentu saja perlu juga memperhatikan peluang yang dapat diraih untuk dpaat membuat pangsa pasar lebih besar. Kebaruan yang ada pada penelitian ini pembuktian bahwa keterhubungan antara persepsi manfaat, persepsi resiko dan kepercayaan merupakan tiga indikator yang tidak dapat dipisahkan. Perusahaan E-wallet yang mampu memberikan persepsi manfaat, persepsi resiko dan kepercayaan yang baik kepada pelanggannya dapat memberi nilai lebih pada penggunaan E-wallet LinkAja. Hasil tersebut selaras dengan riset dilakukan oleh Rahmawati Y.D dan Yuliana (2020). Dari beberapa penelitian mengangkat tema yang sama dengan apa yang akan penulis teliti. Penelitian ini bertujuan melihat pengaruh persepsi yang menyangkut kemudahan, manfaat,resiko, serta kepercayaan terhadap perilaku menggunakan E-wallet LinkAja.

\section{METODE PENELITIAN}

Penelitian ini menggunakan penelitian kuantitatif. Data penelitian ini diambil dari Mahasiswa di Universitas PGRI Semarang angkatan 2017-2020. Data primer pada penelitian ini diambil dari 106 mahasiswa dari masingmasing angkatan 2017-2020. Sebanyak 115 kuesioner disebarkan pada periode bulan Januari hingga Agustus 2021 dengan membagikan kuesioner online.

Sebanyak 106 kuesioner diterima pada penelitian ini sebagai perwakilan sampel dari mahasiswa Angkatan 2017-2020 dan ada 9 kuesioner yang tidak bisa digunakan karena responden tidak mengisi dengan lengkap data yang diminta. Kondisi ini menunjukkan adanya respon rate dalam penelitian ini sebanyak $80 \%$. Hasil dari responden yang telah didapatkan pada penelitian ini diolah menggunakan perangkat SPSS dengan Uji analisis Linier Berganda. Skala pengukuran penelitian ini menggunakan skala Likert dengan 4 nilai. Metode pengukuran skala sikap terdiri dari pemberian skor 1-4 pada setiap jawaban responden agar dapat diolah. Ketentuan yang ditetapkan untuk pengukuran skala Likert, yaitu (1) SS (Sangat Setuju) (2) S (Setuju), (3) TS (Tidak Setuju), dan (4) STS (Sangat Tidak Setuju). Gambar 1 memperlihatkan kerangka pemikiran faktor-faktor yang memengaruhi perilaku penggunaan $E$-wallet Link Aja.

Sampel pada riset ini menggunakan Teknik sampling non probability dengan menggunakan convenience sampling. Metode pengambilan sampel ini digunakan dengan cara memilih sampel secara bebas atas kebijaksanaan peneliti (Sugiyono, 2015). Metode pengambilan sampel ini dipilih untuk memudahkan pelaksanaan penelitian dengan alasan responden yang digunakan adalah mahasiswa yang menggunakan $e$-wallet LinkAja.

Sebelum skala likert, kami membuat definisi dan metrik kinerja untuk setiap variabel yang akan diukur. Definisi operasional dari variabel kemudahan yang dirasakan adalah sejauhmana seseorangmemiliki keyakinan dalam menggunakan sistem tertentu yang tidak memerlukan energi yang berlebih dalam membuat sebuah konsep pengertian (Davis et al. 2000). Indikator kemudahan yang dirasakan antara lain mudah dipahami, mudah dipelajari, mudah digunakan, dan fleksibel digunakan (Pratiwi et al. 2018). Definisi operasional dari variabel manfaat yang dirasakan adalah sejauh mana individu menggunakan manfaat sistem keyakinan dan dapat meningkatkan kinerja mereka (Davis, 1989). Untuk indikator manfaat yang dirasakan yaitu penghematan waktu, diskon dan promosi, efisiensi dan keamanan (Miliani et al. 2013). Definisi operasional dari persepsi risiko adalah ketidakpastian yang akan diterima oleh pengguna ketika menggunakan tekfin (Philips, 200 ). Indikator persepsi risiko meliputi kualitas produk, harga, informasi pribadi, waktu, dan kenyamanan. Definisi operasional kepercayaan menyangkut kepercayaan dan integritas layanan sistem (Daniel dan Mandan, 2017). Metrik keandalan termasuk dapat dipercaya, menjaga privasi, dapat dipercaya, tidak menyesatkan (Sharma dan Kurma, 2016). Sedangkan definisi operasional dari perilaku penggunaan adalah penggunaan aktual dalam hal ukuran frekuensi dan durasi teknologi (Muntianah et al. 2012). Indikator perilaku menggunakan layanan tertentu, intensitas penggunaan, menggunakan tautan hanya untuk kebutuhan, tidak berfungsi. Analisis data yang digunakan dalam penelitian ini yaitu analisis regresi berganda dengan pengolahan data SPSS 22.00. Kerangka pemikiran penelitian selengkapnya pada Gambar 1. 


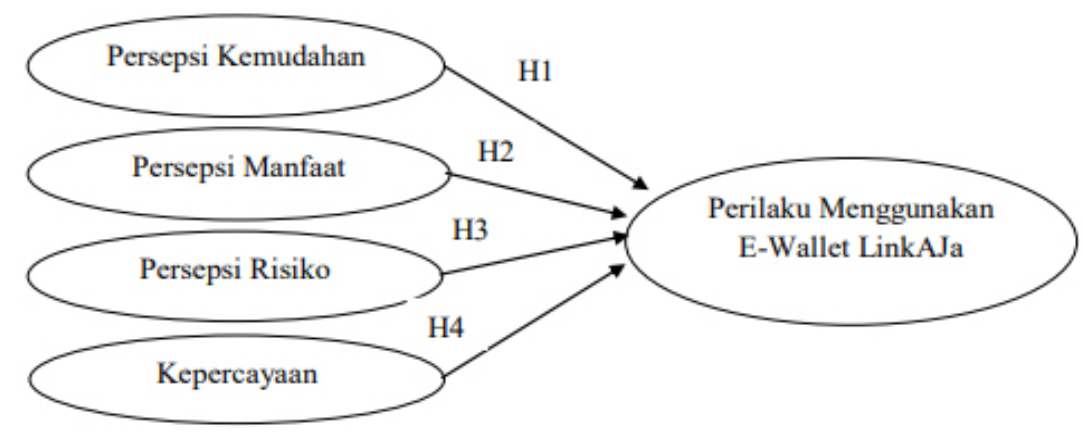

Gambar 1. Kerangka pemikiran penelitian

\section{Hipotesis}

Pengaruh persepsi kemudahan terhadap perilaku menggunakan E-wallet

Menurut Fusilier dan Durlabhji (2000), ada beberapa faktor yang memotivasi seseorang untuk memutuskan menggunakan suatu produk, yaitu mempersepsikan dasar penggunaan sistem teknologi tersebut. Mampu berinteraksi dengan teknologi dan tidak membutuhkan banyak usaha untuk menggunakan teknologi. Kemudahan membuat individu percaya bahwa menggunakan sistem tidak memerlukan banyak usaha. Dalam penelitian yang dilakukan oleh Aldo Putra Kusuma, Syahputra (2020) persepsi kenyamanan berpengaruh positif terhadap sikap penggunaan $e$-wallet. Demikian pula penelitian yang dilakukan oleh Humairoh et al. (2020) Persepsi kenyamanan memiliki pengaruh yang nyata terhadap pertimbangan generasi muda dalam menggunakan e-wallet. Berdasarkan uraian di atas, maka dirumuskan hipotesis sebagai berikut:

H1 : Persepsi kemudahan berpengaruh terhadap perilaku menggunakan $e$-wallet.

Pengaruh persepsi manfaat terhadap perilaku menggunakan e-wallet

Menurut Thompson et al. (1991) menyimpulkan bahwa manfaat teknologi informasi adalah sesuatu yang diharapkan pengguna teknologi informasi dalam pelaksanaan tugas resminya. Thompson (1991) juga menyebutkan bahwa individu akan menggunakan teknologi informasi jika ia mengetahui manfaat positif atau manfaat dari menggunakannya. Oleh karena itu, persepsi manfaat menjadi faktor yang memengaruhi sikap pengguna e-wallet. Dalam penelitian yang dilakukan oleh Aldo Putra Kusuma, Syahputra (2020) bahwa manfaat yang dirasakan berpengaruh positif terhadap sikap penggunaan e-wallet. Senada dengan penelitian Yuliani dan Rahmi (2019) menunjukkan bahwa manfaat yang dirasakan memiliki pengaruh positif terhadap sikap atau keputusan pengguna $e$-wallet. Berdasarkan uraian tersebut, maka terbentuk hipotesis sebagai berikut:

H2 : Persepsi manfaat berpengaruh terhadap perilaku menggunakan $e$-wallet.

Pengaruh persepsi risiko terhadap perilaku menggunakan e-wallet

Secara umum, risiko dapat dipahami dengan cara yang berbeda, misalnya sebagai kejadian yang merugikan, risiko adalah penyimpangan dari hasil yang diharapkan. Risiko umumnya dipahami sebagai perbedaan refleksif dalam distribusi kemungkinan hasil, kemungkinan terjadinya pengguna, dan penilaian subjektif mereka. Risiko dapat diukur dengan non-linier dalam kegunaan mata uang revaluasi atau dengan berbagai keuntungan dan kerugian yang dapat diterima. Dalam penelitian yang dilakukan oleh Maghfira (2017) bahwa persepsi risiko berpengaruh positifterhadap penggunaan $e$-wallet GoPay. Oleh karena itu, konstruksi hipotesisnya adalah sebagai berikut:

H3 : Persepsi risiko berpengaruh terhadap perilaku menggunakan $\boldsymbol{E}$-wallet.

Pengaruhkepercayaan terhadapperilakumenggunakan e-wallet

Kepercayaan telah didefinisikan dalam berbagai cara, dan yang paling umum digunakan diusulkan oleh Mayer et al. (1995) yang mendefinisikan kepercayaan secara harfiah sebagai "kemauan yang tidak pasti untuk tunduk kepada pihak lain". Berdasarkan definisi tersebut, kepercayaan mengacu pada konsep yang mencakup tiga karakteristik, yaitu: kompetensi, "kepentingan" dan integritas (Jarvenpaa et al. 2000). 
Dalam penelitian yang dilakukan oleh Maghfira (2017), kepercayaan berdampak positif terhadap kemudahan penggunaan GoPay. Demikian pula dalam penelitian yang dilakukan oleh Marzella (2020), kepercayaan memiliki pengaruh yang signifikan terhadap keputusan penggunaan e-wallet LinkAja. Berdasarkan uraian di atas, maka dirumuskan hipotesis sebagai berikut:

\section{H4 : Kepercayaan berpengaruh positif terhadap} perilaku menggunakan $e$-wallet

\section{HASIL}

Karakteristik responden dari penelitian ini disajikan dalam Tabel 2 yang terdiri dari beberapa data demografis seperti: tahun Angkatan, jenis kelamin dan keperluan menggunakan E-wallet . Berdasarkan hasil penyebaran kuesioner dapat dijelaskan bahwa pada angkatan tahun 2017 sebanyak 45 dengan persentasi 42,5\%, mahasiswa angkatan 2018 sebanyak 15 dengan presentase 14,2\%, mahasiswa angkatan 2019 sebanyak 36 dengan persentase $34 \%$, dan mahasiswa angkatan 2020 sebanyak 10 dengan presentase 9,4\%. Berdasarkan jenis kelamin jumlah responden dengan jenis kelamin laki-laki dalam penelitian ini berjumlah 21 dengan presentase $19,8 \%$, sedangkan responden berjenis kelamin perempuan berjumlah 85 dengan presentase $80,2 \%$. Untuk karakteristik keperluan menggunakan untuk pembayaran sebanyak 64 dengan presentase $60,4 \%$, keperluan transfer sebanyak 40 dengan presentase $37,7 \%$, dan lainnya (menggunakan semua layanan) sebanyak 2 dengan presentase $1,9 \%$.

Tabel 2. Data demografi

\begin{tabular}{lcc}
\hline Karakteristik & Jumlah & Persentase \\
\hline Tahun Angkatan & & \\
2017 & 45 & $42,5 \%$ \\
2018 & 15 & $14,2 \%$ \\
2019 & 36 & $34 \%$ \\
2020 & 10 & $9,4 \%$ \\
Jenis Kelamin & & \\
Laki-Laki & 21 & $19,8 \%$ \\
Perempuan & 85 & $80,2 \%$ \\
Keperluan Menggunakan E-wallet & \\
Pembayaran & 64 & $60,4 \%$ \\
Transfer & 40 & $37,7 \%$ \\
Menggunakan semua layanan & 2 & $1,9 \%$ \\
\hline
\end{tabular}

\section{Validitas dan Realibilitas Instrumen}

\section{Hasil Uji Validitas}

Hasil analisis dari uji validitas Tabel 3 diketahui bahwa semua variabel nilai $r$ hitung $>r$ tabel, hal ini menunjukkan bahwa pernyataan tersebut mampu mengukur variabel yang ingin diukur, atau pernyataan tersebut semuanya valid. Artinya semua item pernyataan mampu mengukur variabel persepsi kemudahan, persepsi manfaat, persepsi risiko, kepercayaan, dan perilaku menggunakan.

\section{Hasil Uji Reabilitas}

Hasil uji reliabilitas pada Tabel 4 menunjukkan bahwa semua variabel memiliki cronbcah alpha $>0.60$, sehingga dapat disimpulkan bahwa indikator yang digunakan pada variabel yang dipersepsikan adalah nyaman, manfaat yang dirasakan, risiko yang dirasakan, reliabilitas, dan perilaku yang dilaporkan sebagai dapat dipercaya. atau handal sebagai alat ukur.

Tabel 3. Hasil uji validitas

\begin{tabular}{lcccc}
\hline Variabel & Pernyataan & $\mathrm{r}$ hitung & $\mathrm{r}$ tabel & Ket. \\
\hline Persepsi & X1 & 0,748 & 0,190 & Valid \\
Kemudahan & X2 & 0,728 & 0,190 & Valid \\
& X3 & 0,732 & 0,190 & Valid \\
Persepsi & X4 & 0,737 & 0,190 & Valid \\
Manfaat & X5 & 0,810 & 0,190 & Valid \\
& X6 & 0,711 & 0,190 & Valid \\
& X7 & 0,874 & 0,190 & Valid \\
Persepsi & X9 & 0,803 & 0,190 & Valid \\
Risiko & X9 & 0,645 & 0,190 & Valid \\
& X10 & 0,863 & 0,190 & Valid \\
& X11 & 0,780 & 0,190 & Valid \\
& X12 & 0,799 & 0,190 & Valid \\
Kepercayaan & X13 & 0,793 & 0,190 & Valid \\
& X14 & 0,795 & 0,190 & Valid \\
& X15 & 0,819 & 0,190 & Valid \\
& X16 & 0,867 & 0,190 & Valid \\
Perilaku & X17 & 0,746 & 0,190 & Valid \\
Menggunakan & Y1 & 0,748 & 0,190 & Valid \\
& Y2 & 0,803 & 0,190 & Valid \\
\hline \multirow{5}{*}{ Y3 } & 0,793 & 0,190 & Valid \\
\hline & & & &
\end{tabular}




\section{Uji Asumsi Klasik}

\section{Hasil Uji Normalitas}

Dari Tabel 5 dapat terihat bahwa nilai Asymp.Sig (2tailed) adalah 0,859 , sehingga dapat kita lihat bahwa nilai Asymp.Sig (2tailed) $>0,05$ maka dapat disimpulkan bahwa data residual berdistribusi normal.

\section{Hasil Uji Multikolinearitas}

Berdasarkan Tabel 6 dapat diketahui bahwa pengujian ini untuk mengetahui ada atau tidaknya multikolinearitas, dapat dilihat pada nilai tolerance $>$ 0,10 dan VIF andlt; 10. Dari hasil dapat dipastikan bahwa variabel persepsi kenyamanan, manfaat yang dirasakan, risiko yang dirasakan dan keandalan dapat dianggap tidak memiliki masalah multikolinearitas dalam model regresi, sehingga memenuhi persyaratan analisis regresi.

\section{Hasil Uji Heteroskedastisitas}

Berdasarkan Gambar 2, output grafik menunjukkan bahwa titik-titik atau sebaran jawaban responden terdistribusi atau merata dan tidak mengelompok pada satu titik. Ini bisa menjadi proses pengambilan keputusan, yang berarti karena tanggapan responden merata, dapat dikatakan bahwa uji asumsi untuk heterokesdasitas terpenuhi untuk varians variabel.

Tabel 4. Hasil uji reabilitas

\begin{tabular}{lccc}
\hline Variabel & Nilai Cronbach Alpha & Standar Realiabel & Keterangan \\
\hline Persepsi Kemudahan & 0,811 & 0,60 & Reliabel \\
Persepsi Manfaat & 0,815 & 0,60 & Reliabel \\
Persepsi Risiko & 0,800 & 0.60 & Reliabel \\
Kepercayaan & 0,816 & 0,60 & Reliabel \\
Perilaku Menggunakan & 0,817 & 0,60 & Reliabel \\
\hline
\end{tabular}

Tabel 5. Hasil uji normalitas

\begin{tabular}{lll}
\hline One-Sample Kolmogorov-Smirnov Test & & \\
\hline & & Unstandardized Residual \\
\hline $\mathrm{N}$ & Mean & 106 \\
Normal Parameters ${ }^{\mathrm{a}, \mathrm{b}}$ & Std. Deviation & $0 \mathrm{E}-7$ \\
& Absolute & 1.82477201 \\
Most Extreme Differences & Positive & .051 \\
& Negative & .036 \\
& & -.051 \\
Kolmogorov-Smirnov Z & .525 \\
Asymp. Sig. (2-tailed) & .946 \\
\hline
\end{tabular}

a. Test distribution is Normal; b. Calculated from data.

Tabel 6. Hasil uji multikolinearitas

\begin{tabular}{lccl}
\hline Variabel & Tolerance & VIF & Keterangan \\
\hline Persepsi Kemudahan & 0,565 & 1,770 & Tidak ada multikolinearitas \\
Persepsi Manfaat & 0,378 & 2,644 & Tidak ada multikolinearitas \\
Persepsi Risiko & 0,834 & 1,199 & Tidak ada multikolinearitas \\
Kepercayaan & 0,330 & 3,027 & Tidak ada multikolinearitas \\
\hline
\end{tabular}




\section{Hasil Analisis Linear Berganda}

Berdasarkan hasil uji-t (Tabel 7), nilai sig variabel convenience sensor adalah 0,006 dan kolom B bernilai positif 0,341 . Dengan demikian dapat disimpulkan bahwa variabel perceived convenience (persepsi kemudahan) berpengaruh positif terhadap perilaku penggunaan e-wallet LinkAja mahasiswa PGRI Universitas Semarang. Untuk pengaruh manfaat yang dirasakan terhadap perilaku, nilai sig adalah 0,020 , dan pada kolom B nilai negatifnya adalah $-0,314$. Dengan demikian dapat disimpulkan bahwa variabel persepsi manfaat berpengaruh negatif dan signifikan terhadap perilaku penggunaan e-wallet LinkAja di kalangan mahasiswa Universitas PGRI Semarang. Analisis persepsi risiko perilaku diperoleh nilai 0,031 dan pada kolom B nilai negatif $-0,135$. Dengan demikian dapat disimpulkan bahwa variabel persepsi risiko berpengaruh negatif dan signifikan terhadap perilaku penggunaan e-wallet LinkAja mahasiswa PGRI Universitas Semarang. Sedangkan pengaruh keyakinan terhadap perilaku menggunakan nilai signifikansi 0,005 atau lebih kecil dari 0,05 dan kolom B bernilai positif 0,382 . Dengan demikian dapat disimpulkan bahwa variabel kepercayaan berpengaruh positif terhadap perilaku penggunaan e-wallet LinkAja mahasiswa PGRI Universitas Semarang.

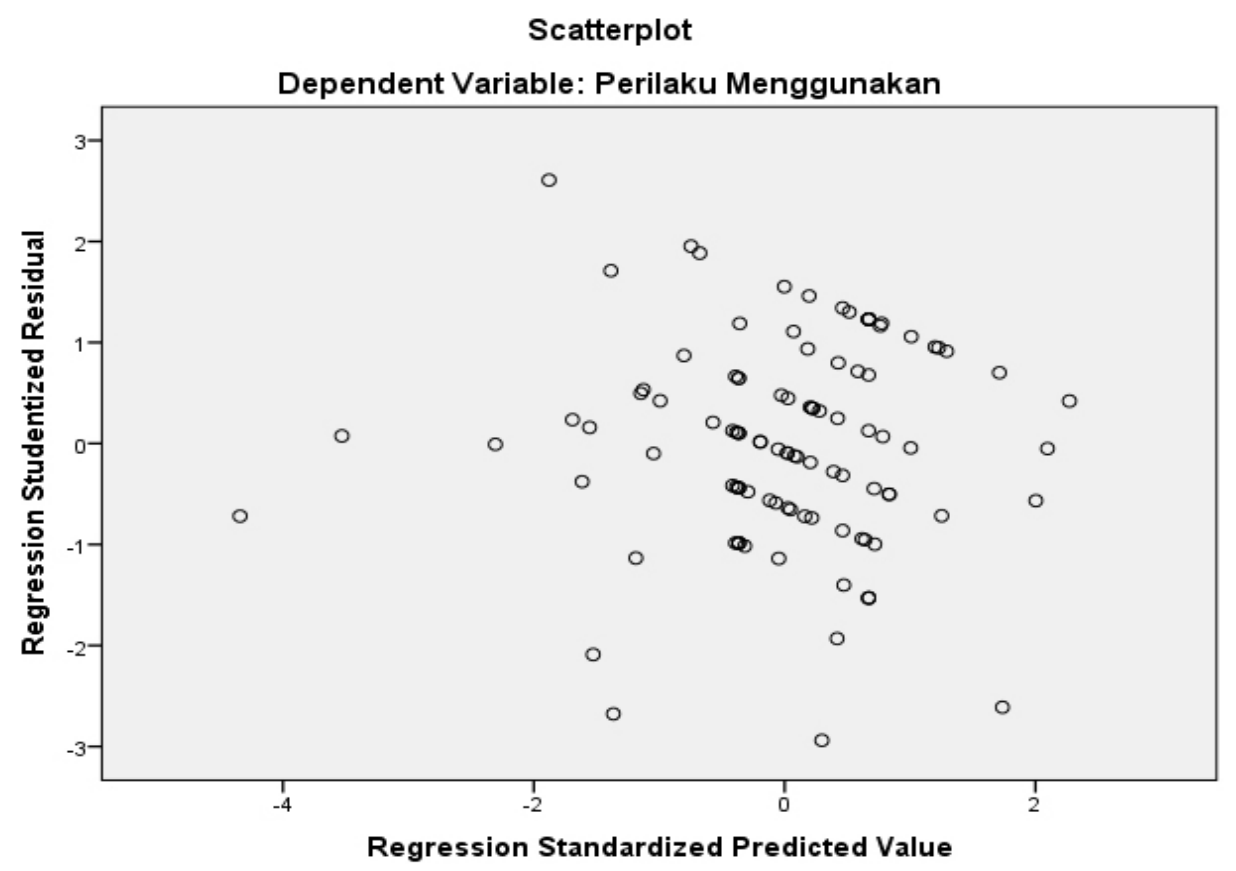

Gambar 2. Hasil Uji Heteroskedastisitas

Tabel 7. Hasil analisis linear berganda

\begin{tabular}{|c|c|c|c|c|c|c|}
\hline \multicolumn{7}{|c|}{ Coefficients $^{\mathrm{a}}$} \\
\hline & \multirow[t]{2}{*}{ Model } & \multicolumn{2}{|c|}{ Unstandardized Coefficients } & \multirow{2}{*}{ 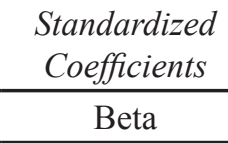 } & \multirow[t]{2}{*}{$\mathrm{t}$} & \multirow[t]{2}{*}{ Sig } \\
\hline & & $\mathrm{B}$ & Std. Error & & & \\
\hline \multirow[t]{5}{*}{1} & (Constant) & 5.935 & 1.403 & & 4.230 & .000 \\
\hline & Persepsi Kemudahan & .341 & .122 & .331 & 2.802 & .006 \\
\hline & Persepsi Manfaat & -.314 & .133 & -.340 & -2.358 & .020 \\
\hline & Persepsi Risiko & -.135 & .061 & -.213 & -2.192 & .031 \\
\hline & Kepercayaan & .382 & .132 & .445 & 2.882 & .005 \\
\hline
\end{tabular}

a. Dependent Variable: Perilaku Menggunakan 


\section{Uji F}

Ftabel $=2,46($ diperoleh dari $\mathrm{F}$ Tabel) $($ Tabel 8), sehingga dapat disimpulkan bahwa nilai Fhitung $>$ Ftabel $(6,49>2,46)$ dengan tingkat signifikansi 0,000 $<0,05$. Kesimpulannya yaitu persepsi kemudahan, persepsi manfaat, persepsi risiko dan kepercayaan secara bersama-sama berpengaruh terhadap perilaku menggunakan $e$-wallet LinkAja.

\section{Uji $\mathbf{R}^{2}$}

Dari Tabel 9 dapat diketahui besarnya nilai adjusted $\mathrm{R}$ square (R2) adalah 0,173 atau $17,3 \%$ maka besarnya pengaruh variabel persepsi kemudahan, persepsi manfaat, persepsi risiko dan kepercayaan terhadap perilaku menggunakan sebesar 0,173 atau $17,3 \%$. Sedangkan $82,7 \%(100 \%$ - 17,3\%) dijelaskan oleh faktor-faktor lain yang tidak disertakan dalam model penelitian ini.

\section{Pengaruh Persepsi Kemudahan Terhadap Perilaku Menggunakan E-wallet LinkAja Pada Mahasiswa UPGRIS}

Persepsi kemudahan memengaruhi perilaku penggunaan e-wallet LinkAja. Hal ini ditunjukkan berdasarkan Tabel 7 yang menunjukkan nilai signifikansi $0,006<0,05$. Dengan demikian dapat disimpulkan bahwa persepsi kenyamanan berpengaruh signifikan terhadap perilaku penggunaan e-wallet LinkAja mahasiswa UPGRIS. Hal ini menunjukkan bahwa persepsi kenyamanan cenderung meningkatkan perilaku penggunaan e-wallet LinkAja, karena melihat produk yang baik karena pengaruh persepsi konsumen tentang kenyamanan, mudah dipahami, mudah digunakan, mudah digunakan. dan penggunaan yang fleksibel, menyebabkan konsumen menggunakan $e$-wallet LinkAja sebagai alat non-pembayaran. Hasil penelitian ini didukung oleh penelitian yang dilakukan oleh Giovani (2020) yang menunjukkan bahwa persepsi kenyamanan berpengaruh positif dan signifikan terhadap keputusan penggunaan e-wallet LinkAja. Hal ini sesuai dengan penelitian yang dilakukan oleh Andryanto (2016) yang menunjukkan bahwa persepsi kenyamanan berpengaruh positif terhadap preferensi pembelian konsumen OLX.id

\section{Pengaruh Persepsi Manfaat Terhadap Perilaku Menggunakan E-wallet LinkAja Pada Mahasiswa UPGRIS}

Persepsi manfaat yang dirasakan memengaruhi perilaku penggunaan e-wallet LinkAja. Hal ini ditunjukkan berdasarkan Tabel 7 yang menunjukkan nilai signifikansi $0,020<0,05$. Sehingga dapat disimpulkan bahwa persepsi manfaat berpengaruh negatif dan signifikan terhadap perilaku penggunaan e-wallet LinkAja mahasiswa UPGRIS. Dalam penelitian ini, manfaat yang dirasakan dengan indikator penghematan waktu, diskon dan promosi, perilaku efektif dan aman saat menggunakan e-wallet LinkAja. Hasil penelitian ini didukung oleh penelitian yang dilakukan oleh Ady Achadi (2020) yang menunjukkan bahwa manfaat yang dirasakan berpengaruh negatif terhadap sikap terhadap penggunaan layanan Go berbayar. Konsisten dengan penelitian yang dilakukan oleh Rahmawati (2019) menyatakan bahwa manfaat yang dirasakan memengaruhi keputusan pengguna ewallet.

Tabel 8. Hasil Uji F

\begin{tabular}{llccccc}
\hline \multicolumn{7}{c}{ ANOVA $^{\mathrm{a}}$} \\
\hline Model & & Sum of Squares & Df & Mean Square & F & Sig. \\
\hline 1 & Regression & 89.957 & 4 & 22.489 & 6.497 & $.000^{\mathrm{b}}$ \\
& Residual & 349.628 & 101 & 3.462 & & \\
& Total & 439.585 & 105 & & & \\
\hline
\end{tabular}

a. Dependent Variable: Perilaku Menggunakan; b. Predictors: (Constant), Kepercayaan, Persepsi Risiko, Persepsi Kemudahan, Persepsi Manfaat

Tabel 9. Hasil Uji R²

\begin{tabular}{lllll}
\hline \multicolumn{4}{c}{ Model Summary $^{\mathrm{b}}$} \\
\hline Model & $\mathrm{R}$ & $\mathrm{R}$ Square & Adjusted R Square & Std. Error of the Estimate \\
\hline 1 & $.452^{\mathrm{a}}$ & .205 & .173 & 1.861 \\
\hline $\begin{array}{l}\text { a. Predictors: (Constant), Kepercayaan, Persepsi Risiko, Persepsi Kemudahan, Persepsi } \\
\text { Perilaku Menggunakant; b. Dependent Variable: }\end{array}$
\end{tabular}




\section{Pengaruh Persepsi Risiko Terhadap Perilaku Menggunakan E-wallet LinkAja Pada Mahasiswa UPGRIS}

Persepsi risiko berpengaruh signifikan terhadap perilaku penggunaan e-wallet LinkAja. Hal ini ditunjukkan berdasarkan Tabel 7 yang menunjukkan nilai beta sebesar 0,135 dengan nilai signifikansi 0,031 etlt; 0,05. Sehingga dapat disimpulkan bahwa persepsi risiko berpengaruh negatif dan signifikan terhadap perilaku penggunaan e-wallet LinkAja. Dalam penelitian ini, persepsi risiko dengan indikator kualitas produk, harga, informasi pribadi, waktu dan kenyamanan. Hasil penelitian ini sejalan dengan penelitian yang dilakukan oleh Ady (2020) yang menunjukkan bahwa persepsi risiko berpengaruh negatif terhadap penggunaan e-wallet GoPay.

\section{Pengaruh Kepercayaan Terhadap Perilaku Menggunakan E-wallet LinkAja Pada Mahasiswa UPGRIS}

Kepercayaan memengaruhi perilaku penggunaan e-wallet LinkAja. Hal ini ditunjukkan berdasarkan Tabel 7 yang menunjukkan nilai signifikansi 0,005 dan 1t; 0,05 . Sehingga dapat disimpulkan bahwa kepercayaan berpengaruh positif signifikan terhadap perilaku penggunaan $e$-wallet LinkAja pada mahasiswa PGRI Universitas Semarang. Hasil penelitian ini didukung oleh penelitian yang dilakukan oleh Safarudin et al. (2020) yang menunjukkan bahwa kepercayaan berpengaruh positif terhadap loyalitas Gen $\mathrm{Z}$ terhadap penggunaan fintech ewallet pada pengguna ewallet lahir rentan antara tahun 1996 dan 2003. Semakin konsumen memiliki kepercayaan terhadap suatu produk, semakin yakin mereka akan menggunakan produk tersebut. Hal ini sesuai dengan penelitian Maghfira (2018) yang menyatakan bahwa kepercayaan berpengaruh positif terhadap penggunaan GoPay.

\section{Implikasi Manajerial}

Secara implikasi, penelitian ini menunjukkan bahwa pentingnya bagi suatu perusahaan E-wallet dalam menerapkan kemudahan dalam penggunaan aplikasi E-wallet, memberikanbanyakmanfaatkepadapengguna aplikasi E-wallet, mengurangi terjadinya resiko dalam penggunaan E-wallet yang berhubungan dengan keamanan data pribadi maupun aspek privasi lainnya serta dapat meningkatkan nilai kepercayaan pengguna $E$-wallet. Oleh karena itu, pengelolaan aplikasi $E$-wallet didalam memberikan kemudahan, manfaat, rasa aman dan meningkatkan kepercayaan konsumen harus terus dikembangkan, dengan demikian performa perusahaan E-wallet dalam hal ini LinkAja akan terjaga. Penelitian ini juga memberikan informasi bahwa pentingnya penerapan TAM (Technology Acceptance Model) bagi manajemen perusahaan. TAM memiliki peran untuk menjaga kualitas dari manajemen perusahaan yang nantinya akan berdampak pada kualitas produk dari perusahaan. Sehingga, nantinya output dari perusahaan dapat memuaskan harapan dari pelanggan.

\section{KESIMPULAN DAN SARAN}

\section{Kesimpulan}

Penggunaan e-wallet LinkAja oleh mahasiswa PGRI Universitas Semarang berpengaruh positif dan signifikan terhadap persepsi kenyamanan. Dari hasil tersebut dapat diketahui bahwa mahasiswa FEB Universitas PGRI Semarang merasa mudah dalam menggunakan e-wallet LinkAja sebagai pembayaran transaksi non tunai, seperti saat menggunakan $e$-wallet LinkAja mudah dipahami, mudah untuk dipelajari, mudah digunakan, dan fleksibel untuk digunakan.

Persepsi manfaat berpengaruh negatif dan signifikan terhadap penggunaan $e$-wallet LinkAja oleh mahasiswa Universitas PGRI Semarang. Hal ini dilatarbelakangi oleh kenyataan bahwa siswa mendapatkan keuntungan dari penggunaan $e$-wallet LinkAja, sehingga ketika siswa merasakan manfaat menggunakan e-wallet LinkAja untuk membayar transaksi non tunai, mereka menjadi malas menggunakan e-wallet LinkAja untuk membayar. untuk transaksi tunai.

Persepsi risiko berpengaruh negatif signifikan terhadap penggunaan e-wallet LinkAja oleh mahasiswa Universitas PGRI Semarang. Berdasarkan hasil tersebut, siswa merasakan risiko yang dapat diterima saat menggunakan LinkAja eWallet, sehingga kesadaran pengguna yang tinggi akan risiko penggunaan LinkAja eWallet akan mengurangi jumlah pengguna LinkAja eWallet. 
Kepercayaan berpengaruh positif dan signifikan terhadap perilaku mahasiswa Universitas PGRI Semarang dalam menggunakan e-wallet LinkAja. Berdasarkan hasil tersebut, mahasiswa percaya bahwa $e$-wallet LinkAja melindungi privasi konsumen, dapat diandalkan, dan tidak curang saat melakukan transaksi pembayaran non tunai.

\section{Saran}

Keterbatasan penelitian ini yaitu sampel memiliki keterbatasan karena menggunakan Teknik convenience sampel sehingga sampel tidak dapat mewakili secara merata. Untuk penelitian selanjutnya bisa menggunakan teknik pengambilan sampel secara random agar semua responden memiliki hak yang sama untuk dipilih menjadi sampel. Keterbatasan lain dari penelitian ini adalah besarnya pengaruh variabel persepsi kemudahan, persepsi manfaat, persepsi risiko dan kepercayaan secara simultan terhadap perilaku menggunakan sebesar 0,173 atau $17,3 \%$. Sedangkan $82,7 \%$ dipengaruhi oleh variabel lainnya yang belum ada pada penelitian ini, sehingga untuk penelitian selanjutnya disarankan untuk bisa menggunakan variabel lainnya yang belum diteliti dalam penelitian ini seperti variabel persepsi harga, brand image, serta literasi produk.

Pengelolaan aplikasi E-wallet didalam memberikan kemudahan, manfaat, rasa aman dan meningkatkan kepercayaan konsumen harus terus dikembangkan, dengan demikian performa perusahaan E-wallet dalam hal ini LinkAja akan terjaga. Pentingnya penerapan TAM (Technology Acceptance Model) bagi manajemen perusahaan. TAM memiliki peran untuk menjaga kualitas dari manajemen perusahaan yang nantinya akan berdampak pada kualitas produk dari perusahaan. Sehingga, nantinya output dari perusahaan dapat memuaskan harapan dari pelanggan.

\section{DAFTAR PUSTAKA}

Achadi A. 2020. Pengaruh pengetahuan produk, persepsi resiko dan persepsi manfaat terhadap minat menggunakan layanan GoPay pada pelanggan Gojek. Jurnal MIMB 17(1):11-23.

Andryanto R. 2016. pengaruh kepercayaan, persepsi risiko, dan persepsi kemudahan penggunaan terhadap minat beli di toko online (Studi empiris yang dilakukan pada OLX.Co.id di Yogyakarta) [skripsi]. Yogyakarta: Universitas Negeri

\section{Yogyakarta.}

Chauhan S. 2015. Acceptance of mobile money by poor citizens of India: Integrating trust into the technology acceptance model. Info 17(3):58-68. https://doi.org/10.1108/info-02-2015-0018

Davis FD. 1989. Perceived usefulness, perceived ease of use, and user: Acceptance of information technology. MIS Quarterly 13(5):319-339. https/ doi.org/10.2307/249008

Davis FD et al. 2000. A theoretical extension of the technology acceptance model: Four longitudinal field studies. Management Science 46(2):186204. doi.org/10.1287/mnsc.46.2.186.11926

Giovani AD. 2020. Analisis penggunaan e-filing dengan TAM yang dimoderasi pengalaman pemakai sistem. Jurnal Akuntansi dan Pajak 21(1). http:// dx.doi.org/10.29040/jap.v21i1.1033

Haris B. 2020. Formulasi strategi pengembang digital banking (studi kasus Bank ABC). Jurnal Aplikasi Bisnis \& Manajemen 6(3):489-500. https/doi. org/10.17358/jabm.6.3.489

Koloseni D, Mandari H. 2017. Why mobile money users keep increasing? Investigating the continuance usage of mobile money services in Tanzania. Journal of International Technology and Information Management 26(2). https:// scholarworks.lib.csusb.edu/jitim/vol26/iss2/6

Kotler P. 2004. Marketing Management, The Millenium Edition. New Jersey: Prentice Hall.

Miliani, Indriani MTD. 2013. adoption behavior of e-money usage. Information Management and Business Review AMH International 5(7):369378. https/doi.org/ 10.22610/imbr.v5i7.1064

Muntianah. 2012. Pengaruh minat perilaku terhadap actual use teknologi informasi dengan pendekatan teory acceptance model. Profit 6(1). DOI https:// doi.org $/ 4564$

Magfira. 2018. Japanese Non-verbal Communication by the Main Characters in the Novel of Totto-chan and the Light on Curtain of Sakura (An Analysis of Kinesics) [thesis]. Makasar: Universitas Islam Negeri Alauddin Makassar.

Putra KA, Syahputra. 2020. Pengaruh persepsi kemudahan dan persepsi manfaat terhadap sikap penggunaan E-Wallet di Kota Bandung .Journal of Applied Business 4(2). https://doi. org/10.30871/jaba.v4i2.2080

Rahmawati YD, Yualiana RY. 2020. Pengaruh persepi manfaat, kemudahan dan keamanan terhadap keputusan penggunaan e-wallet. ECOBANK: Journal of Economics and Banking 2(2):157-168. 
https://doi.org/10.35829/econbank.v2i2.100

Sarafudin A, Kusbiyo L, Senalasari W. 2020.Faktorfaktor pembentuk loyalitas generasi $\mathrm{z}$ dalam menggunakan financial technology e-wallet. Prosiding industrial Reseacrh Workshop and National Seminar 11(1):1073-1078.

Sugiyono. 2017. Statistika Untuk Penelitian. Bandung: Alfabeta CV.
Pratiwi, Indriani, Sugiarto. 2018. Analisis pengaruh technology readiness terhadap minat menggunakan T-Cash di Kota Semarang. Jurnal Bisnis Strategi 26(1):76-88. https://doi. org/10.14710/jbs.26.1.76-88

Sharma V, Chaudhary RR. 2016. Uncertain Supply Chain Management. Growing Science. 